\title{
Digital Marketer's Capability in Handling Marketing Products and Services on Instagram
}

\author{
Yusuf Hamdan*, Anne Ratnasari, Aning Sofyan, Yenni Yuniati \\ Faculty of Communication \\ Bandung Islamic University \\ Bandung, Indonesia \\ *yuyu@unisba.ac.id, Anne.ratnasari@unisba.ac.id, Aning@unisba.ac.id, Yenni.yuniati@unisba.ac.id
}

\begin{abstract}
Digital marketing is an important effort in selling products or services in this digital era and this new technology world. Digital marketers' duties are not only growing brand awareness and increasing product sales, but also being an option in obtaining feedback on products released to the market. Therefore, a digital marketer is required to build closeness with costumers. This study aims to analyze the digital marketer skills of Sekolahbisnisonline.id in dealing with marketing products and services. The purpose of this study is to analyze the ability of digital marketers in composing advertising messages, the ability to overcome obstacles in using Instagram, and create closeness with costumers. This research method uses qualitative research methods with a case study approach. This study found digital marketers were able to compose advertising messages, were able to overcome obstacles in using Instagram, and were able to build relationships with costumers, so that costumers connected to the products or services being sold.
\end{abstract}

Keywords-digital marketer, marketing, products, services, Instagram

\section{INTRODUCTION}

In the digital era, marketing strategies are increasingly developing following technological advances. Now marketing does not only rely on conventional methods and media, but also relies on the internet world. Based on Statista.com data, in a period of 12 years (2007-2019), the growth of global advertising on the internet could increase 12 times. This figure continues to grow, companies intensively optimize the use of media marketing. Especially when the Covid 19 outbreak occurred globally, the Government asked the public to stay at home. People who usually do activities outside the home are now spending more and more time at home, this has led to changes in costumer behavior. Even though they live at home, the community is still active so they can work, study, shop, and do other activities from home. Because people work from home, one of the supporters of this activity is internet. For companies, this condition is a situation that opens up opportunities, including an effective way to reach costumers by utilizing digital marketing. Forms of digital marketing activities include advertising, sales promotion, direct marketing, and word of mouth [1]. Digital marketing media used by business people include websites, Facebook, Instagram, and Twitter.

The management team of Bisnisonline.id carries out digital marketing activities in marketing products and services, and one of the media used is Instagram. Digital marketing has an important role in advancing companies such as reaching costumers. People who carry out digital marketing activities are called digital marketers.

Sekolahbisnisonline.id digital marketers in handling the marketing of products and services carry out three activities; compiling advertising messages, overcoming obstacles in using Instagram, and creating closeness with costumers. Based on this explanation, it is necessary to conduct research on the ability of digital marketers to handle marketing of products and services on Instagram.

\section{Digital Marketer}

Currently, digital marketers are one of the professions that play a major role in helping to market and maximize the business being run, especially in achieving sales targets. Marketing or promotion activities are part of marketing communication activities. It is used by companies to inform, persuade, and remind costumers about the products and brands sold [2]. The objectives of marketing communication are achieved through partnership relationships that include engagement, creation, maintenance and enhancement of strong relationships with costumers, where costumers bring friends, family members and others to do business with the company $[1,3]$.

Digital marketers have duty to build brand awareness in costumers so that products will always be remembered by costumers, and create lead generation, which is to collect costumer data using the media. In carrying out this task, digital marketers have a big responsibility, and are required to have high creativity.

Singh R [4] conducted a study on the similarity of social networks among millennials and their impact on social advertising: challenges for digital marketers. The results found that gender has no impact on the similarity of social 
networking sites. Guerini and Minelli [5] examined the subjective side of DiDIY (Digital Do It Yourseft): the profile of creators in the network marketer community, a study on digital marketers. The study found that DiDIYer's initial profile in the network marketing community was suitable for further comparative study. This exploratory study recognizes the most important antecedents of DiDIY in digital literacy, including awareness of being digital literacy and / or a suitable candidate, and in organizational culture.

This research focuses on analyzing the ability of digital marketers in composing advertising messages, the ability to overcome obstacles in using Instagram, and creating closeness with costumer. The ability of digital marketing to compose advertising messages including verbal and nonverbal messages is one of the keys to success in marketing products and services.

Verbal messages are messages in communication in the form of speech, either verbally or in words. The choice of words (diction) in verbal messages has an important role in marketing products and services. Because the words spoken have an impact both on themselves and on others. These words have a positive and negative sides [6,7]. Therefore, to increase business success, digital marketers try to use positive words, so that their hopes will actually come true. In order to produce positive sentences requires skills that are supported by high motivation to maintain a positive situation in the resulting discourse [8,9]. Nonverbal messages include all stimuli (except verbal stimuli) in a communication setting, which is generated by the individual and the use of the environment by the individual [10].

Nonverbal messages are the creation and exchange of messages by not using words, but using body movements, gestures, eye contact, facial expressions, proximity and touch [11].

Digital marketers manage Instagram as a communication medium to market products and services to costumers. From this goal, digital marketers will know how much the media reach, how often costumers see the media, and how much the media generates product sales.

In creating closeness with costumers, among others, by building partnerships through hospitality, trust, self-disclosure, and responsibility [12]. A happy person will create a friendly and pleasant atmosphere. Such a situation according to DeVito [13], will positively encourage individuals to become friends to interact [13]. Digital marketers can take advantage of this situation to build closeness with costumers.

The company is claimed as successful if it is able to carry out good cooperation with costumers. Forms of communication that companies make with costumers include addressing costumer complaints, serving consultation on problems experienced by costumers, and providing solutions to costumers at the right time [1].

\section{METHODS}

Research on the Ability of Digital Marketers in Handling Marketing of Products and Services on Instagram was held in collaboration with a team of lecturers at the Faculty of Communication Sciences, Bandung Islamic University. The research problem is how the Digital Marketer's Ability to Handle Marketing of Products and Services on Instagram. The research objectives are to analyze the ability of digital marketers in composing advertising messages, the ability to overcome obstacles in using Instagram, and create closeness with costumers. This research method uses case studies in the form of a single case design, in which the researcher maintains the holistic and meaningful characteristics of real-life events $[14,15]$. The research unit of research on the ability of digital marketers in marketing products and services on Instagram is seen in the aspect of composing advertising messages, the ability to overcome obstacles in using Instagram, and creating closeness with costumers. The informants of this research are digital marketers and the school management team of Bisnisonline.id.

\section{FINDINGS}

\section{A. Digital Marketer's Ability in Composing Advertising Messages on Instagram}

Digital marketers compose verbal and nonverbal advertising messages in marketing products and services to costumers. Based on the research findings, Instagram schoolbisnisonline.id has 347,000 followers and has posted 8,573 shared photos. Information from Instagram profiles includes brief information about tips and learning about online business, participants are spread across 17 countries, addresses, phone numbers (WhatsApp) (Instagram schoolbisnisonline.id).

Instagram can only load short photos and videos that are about 30 seconds long, so digital marketers design and choose well the photos and videos to share. The contents of the Instagram message display, among others, photos of activities in online business school classes, quotes, testimonials, and short videos such as making product photos, how to edit videos, creating Instagram feeds, making catalog photos, making marketing videos, and others

Sekolahbisnisonline.id's Digital Marketer explained that verbal and nonverbal messages were intended to inform business learning activities, study business support media, and to market products or services. From this media, it was seen how much interest the followers have and able to see the number of likes from followers or comments from followers.

Based on the explanation of the owner of the school businessonline.id (10 May 2020), the use of Instagram really helps the company in explaining products and services to costumers. Figure 1 is one form of learning services offered by Sekolahbisnisonline.id. 


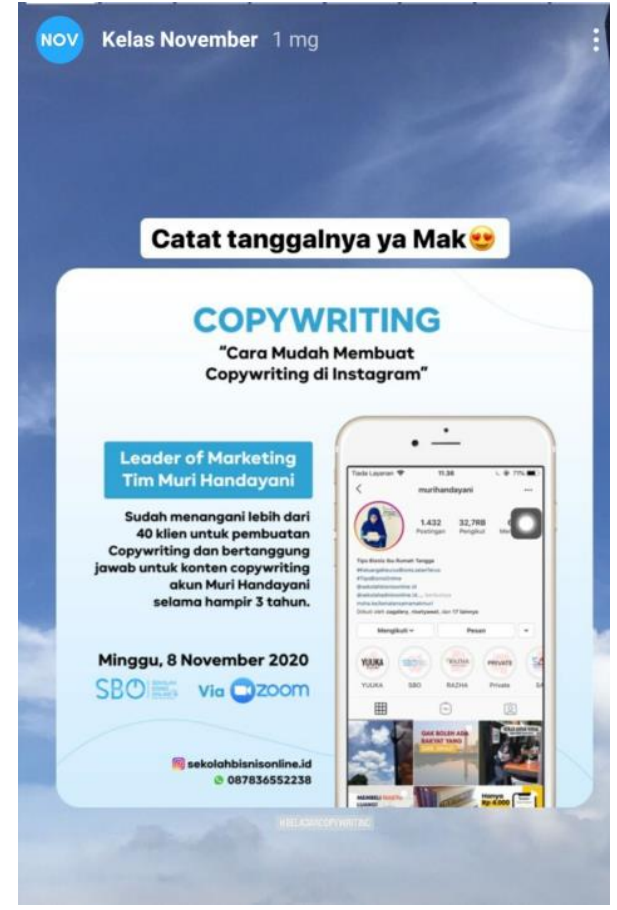

Fig. 1. Sekolah Bisnis Online’s Instagram [16]

According to an informant as a digital marketer, (interview, 2 Oktover 2020) explained that the preparation of advertising messages relies on various aspects, one of which is creativity. This is intended so that the design of the advertising message is not monotonous and able to attract the attention of costumers.

Instagram has a unique value because by posting photos or videos, it can provide deep meaning to those who see it. On the Instagram menu, there are hashtags that are useful for increasing interest based on certain categories when used by others. For example, hashtags used in schoolbusinessonline.id are \#sekolahbisnis, \#sekolahonline. \#belajarjualanonline, \#internetmarketing, and others. These words often arise, and are often used to make it easier to find out about Sekolahbisnisonline.id.

The informant stated that before using communication media, they must first study the capabilities of the media to be used, including using Instagram which is very helpful for promotional activities, because this media can create costumer awareness of the products and services offered.

Sekolahbisnisonline.id informed about learning packages such as learning to make product photos, editing videos, internet marketing, and other forms of learning. The objectives to be achieved include not only informing products and services but also communicating with potential customers. For example, costumers ask about the availability of time, materials and learning methods. Another goal is to share motivation, expand social networks, to convey opinions or views, especially to support costumer understanding in understanding learning materials that can be applied in marketing their business fields.

\section{B. Ability to Overcome Barriers to using Instagram}

Based on interviews with digital marketers (4 October 2020 ) in using Instagram as a medium to market products and services, there are several obstacles encountered, including the serving of advertisements from other products and services that interfere with opening the Instagram application, these ads suddenly appear. Digital marketers in managing Instagram require special time and great attention, such as updating activities, photos, or videos.

Another aspect that becomes an obstacle is costumer awareness in using social media, especially Instagram. Costumers often do not have the time, lack attention, do not understand how to use the media. The information presented on Instagram is very short, so it often causes costumers to misinterpret the information they receive.

These findings are the main focus of learning at the Online Business School, because according to the informant's opinion, this is a problem for most people, so that he as a digital marketer must be creative in finding ways so that things experienced by costumers have a solution. The effort is providing insights to costumers learning learning materials that in reality there is a phenomenon of advertising like that, as a digital marketer, suggesting that future participants in serving advertisements must look for suitable media, and costumer's time.

To deal with busy and inattentive costumers, digital marketers plan product development, make innovations and improvements by providing something unique that is the hallmark of Sekolahbisnisonline.id. In addition, digital marketers are trying to be creative people, by offering discounts on products, and adding more free gifts in the form of costumers being able to try participating in learning materials in a short time.

\section{Ability to Create Closeness with Costumers}

Digital marketers in creating closeness with costumers, among others, by maintaining the quality and characteristics of products and services, as well as learning methods. This is in accordance with the opinion of the informant (interview 3 August 2020), saying, "In running a business, the Online Business School maintains quality, characteristics, and learning methods. As entrepreneurs in the field of training for beginner women entrepreneurs, we are trained to be disciplined in monitoring the accuracy of learning materials. If any of the participants are successful in running a business after having training from us, it is a joy. We realize this is obtained as a result of patience in which other parties are satisfied with the quality of the company's products.

The research informant said (interview 2 October 2020) "We are committed to maintaining the best and distinctive products. For example, we address training participants with the term "Mak", which means mother, as a term used in parts 
of Indonesia. Our company limits the participants who will study at our place to only women and mothers, this is the hallmark of our business. Our company research team tries to understand what the trainees want by being a good listener. In addition, the company pays close attention to the interests of the participants by immediately following up on what the participants want. For example, in today's digital era, many companies communicate with costumers face-to-face, apart from using the media that people usually use and using social media. We will immediately hold training for participants who want to learn internet marketing. Furthermore, the informant explained that another aspect of creating closeness with costumers is having a very basic and easy to learn learning method, using everyday language that is easily understood by the training participants.

The research findings regarding the benefits of creating closeness to costumers according to informants (interview 3 October 2020) is to promote of products and services offered to costumers. Advertising messages explain aspects that can attract costumers to join, such as giving discounts tailored to certain events that occur in society, or providing materials to costumers for free. Another benefit obtained is to find out costumer opinions after participating in learning at the Online Business School. This costumer opinion helps in marketing products or services to costumers.

\section{CONCLUSION}

First, the digital marketer's ability in composing verbal and nonverbal advertising messages. The message is intended to inform business learning activities, study business support media, and to market products or services.

Second, the obstacles in using Instagram include when opening the Instagram application there is an annoying ad serving, and costumers are not paying attention. Digital marketers' efforts to overcome costumers who are not paying attention include planning product development by making innovations, offering product discounts, and giving free gifts.
Third, digital marketers create closeness with costumers by maintaining quality, and maintaining the characteristics of products and services, as well as through learning methods that are very basic and easy to learn, and use everyday language that is easy for costumers to understand.

\section{REFERENCES}

[1] T.A. Shimp, Komunikasi pemasaran terpadu dalam periklanan dan promosi. Jakarta: Salemba Empat, 2014.

[2] P. Kotler and K. Keller, Manajemen Pemasaran (Jilid Dua Edisi Keduabelas),. Jakarta: PT Index, 2007.

[3] P. Kotler and G. Armstrong, Prinsip-prinsip pemasaran jilid 1 edisi 12 Jakarta: : Erlangga, 2008.

[4] R. Singh, "Monotony of social networking among millennial and its effect on social advertisement: a challenge to digital marketers," Young Consum., 2016.

[5] C. Guerini and E. A. Minelli, "The subjective side of DiDIY: the profile of makers in network marketers communities," Data Technol. Appl., 2018

[6] H. Urban, Positive Words, Powerful Results (Terj. Eta Sitepoe). Jakarta: PT Bhuana Ilmu Populer., 2007.

[7] Y. Oswald, Keajaiban Kata-Kata: Ubahlah Hidup Anda dengan KataKata yang Positif. Jakarta: PT Gramedia Pustaka Utama, 2009.

[8] T.D. Waringin, Marketing Revolution. Jakarta: : PT Gramedia Pustaka Utama, 2008

[9] Watono, Periklanan. Jakarta: Dwi Saota, 2008

[10] D. Mulyana, Metode Penelitian Kualitatif. Bandung:, 2002.

[11] Prasetyono, Promosi.Terj.Harya B.S, dkk. Jakarta: Salemba Empat, 2007.

[12] M. Budyatna and L. M. Ganiem, Interpersonal Communication Theory. Jakarta: Kencana, 2011

[13] J. DeVito, Komunikasi Antar Manusia. Bandung: Alfabeta, 2013.

[14] L.J. Moleong, Metodologi Penelitian Kualitatif. Bandung: PT. Remaja Rosda Karya, 2004.

[15] R.K. Yin, Studi kasus: desain dan metode. Jakarta: Raja Grafindo Persada, 2002.

[16] "Sekolah Bisnis Online, 2020.” 